\title{
Student responses to active learning strategies: A comparison between project-based and traditional engineering programs
}

\section{Dr. Elizabeth Pluskwik, Minnesota State University, Mankato}

Elizabeth leads the Engineering Management and Statistics competencies at Iron Range Engineering, an ABET-accredited project-based engineering education program located in northern Minnesota. She enjoys helping student engineers develop entrepreneurial mindsets through active and collaborative learning in the classroom, on project design teams, and while out on co-op placement. Her prior education and industry experience are in business and accounting, and her Ph.D. in Organization and Management is from Capella University, Minneapolis. She holds Six Sigma and Lean certifications.

\section{Dr. Yuezhou Wang, Minnesota State University, Mankato}

Dr. Yuezhou Wang is a Mechanical Engineering faculty in Minnesota State University, Mankato. After receiving his Ph.D. from University of Minnesota in 2017, he works for Iron Range Engineering, a project-based learning program. His teaching interests are in areas of materials science, structural analysis, finite element modeling and dynamic systems. His technical research focuses on multiscale modeling on mechanical behavior of nano and granular materials. 
Student responses to active learning strategies:

A comparison between project-based and traditional engineering programs

\section{Introduction}

Over the past three decades, engineering education has experienced calls for innovation in terms of effective teaching and learning. One of the reformations is to introduce active learning in the classroom to promote students' engagement. Different from traditional teacher-centered lectures, active learning [1] focuses on students' participation, peer-to-peer interaction as well as learning reflection and metacognition [2]. Including a wide range of teaching strategies, such as group brainstorming, jigsaw discussion [3], think-pair-share [4], and problem-based activities [5], active learning not only improves students' academic performance [6,7], but also significantly enhances their retention rate in the STEM fields [8].

In spite of the benefits reported by a myriad of studies, the translation of theory into classroom practices has unfortunately remained relatively slow in progress [9]. Besides the reluctance from instructors to spend the necessary time to prepare interactive teaching materials [10], students' resistance to active learning also plays a crucial role. It is understandable that lack of students' participation would further hinder the instructors' motivation to develop in-class activities. To clearly assess such resistance, DeMonbrun et al. [11] developed a systematic questionnaire known as the Student Response to Instructional Practices (StRIP) survey instrument. Grounded in Expectancy-Value Theory [12], the StRIP instrument aims to assess three aspects of student resistance [13] to active learning strategies:

1. Strategies to reduce resistance. The StRIP survey collects data on two strategies to reduce student resistance: explanation and facilitation. Explanation is defined as the instructor's verbal promotion of the value of the activity. Facilitation means how much support the instructor provides during the activity.

2. Affective response. This part of the survey inquires about students' perceptions of value creation in the learning activity and their attitude towards active learning.

3. Behavioral response. This part is designed to measure students' self-evaluation of their participation and potential distractions during the learning activity.

Since 2017, the StRIP instrument has been completed by more than 1,000 students in US university engineering programs. Seventeen engineering faculty have also been interviewed by researchers [14]. While many students embrace active learning and report positive learning experiences [1517], the evidence-based results have also revealed a few reasons for their resistance. One of the major concerns was lack of motivation. In other words, some students would not see the value in the new learning techniques. Additionally, distraction coming from the internet or social media sometimes negatively impacts their learning efficiency. It could become worse with a large class size, where effective classroom management may fall short. Student resistance may be mitigated 
by improved explanation and facilitation. First, for explanation, the instructor could make activities clearly connected to learning goals and provide clear instructions before those activities. Equally important, students also need to be familiarized with the expectation as well as challenging aspects of an open-ended activity [19]. Second, some simple facilitation strategies [14] such as soliciting students' feedback and walking around the classroom and approaching non-participating students can be effective strategies in facilitating students' engagement. It is also recommended that the instructor use low stakes grading in the activities at the beginning and gradually withdraw facilitation [20] as the students become more self-directed.

\section{Research Motivation}

While the current research done with the StRIP instrument has covered a number of specific engineering classes, we are interested in evaluating the students' potential resistance across an entire engineering program that is dedicated to providing students with active learning experiences. Founded in 2010, the Iron Range Engineering (IRE) program transforms the landscape of engineering education with its philosophy of integrated engineering, project-based learning combined with an entrepreneurial mindset. Project-based learning (PBL) is inherently active in nature, as students work with industry clients on a design or entrepreneurial project each semester delivered in a 3-credit design class, repeated every semester in their 3rd and 4th years of the undergraduate program. The 1 st and 2 nd year students enrolled in an affiliated community college complete "in-house" project. Teams in both programs are mentored by "facilitators", who guide and direct project teams as they gain technical, professional, and design skills. Students are encouraged to develop self-directed learning skills throughout the four-year program, which culminates in a Bachelor of Science in Engineering degree. Technical course class sizes are small, ranging from six to thirty students per instructor, class meetings are delivered in "learning conversations", and students are guided to increasing levels of autonomy and leadership as they progress through the program. Classrooms are arranged in workshop style, with moveable tables and chairs. White boards are plentiful, and students often work in small groups at the white boards solving problems. Content delivery is primarily in the flipped classroom style, with a small amount of lecture given in conjunction with answering student questions on the videos, articles, and other learning resources. Eight hours per week of in-class time and sixteen hours of out of class work are expected. Combined with twelve hours per week of open-ended project work in small teams ( 3 - 5 students per team) in their own project rooms, the students in this program spend 20 - 25 hours per week learning with groups of peers, primarily in an active learning environment.

A small number of previous studies have examined students' perceptions about how frequently their instructors used different types of active learning practices, how frequently their instructors used explanation and facilitation strategies to reduce student resistance to these active learning practices, and students' affective and behavioral responses that resulted. None of the previous studies were done in a project-based learning environment, however, and none of them targeted 3 rd and 4th year learners in their samples. Several public and private institutions and a variety of course disciplines were sampled in previous studies, 1st through 4th-year interdisciplinary 
engineering students in a project-based program have not been measured with the StRIP instrument. That motivates the current study. Although the sample size is small $(n=49)$, this study presents some initial findings from a project-based engineering education program. We asked approximately 100 students enrolled in an integrated engineering program covering first through fourth years of study in Minnesota State University, Mankato (MNSU) to address the following research questions:

1. What are students' perceptions about how frequently their instructors used different types of instruction in a project-based engineering program?

2. What are students' self-reported affective and behavioral responses when their instructors used active learning strategies?

3. Do the findings from this study differ significantly from the previous studies on non-PBL program students?

Research Method, Population and Settings

In Spring 2019, undergraduate students in three closely related programs participated in our study. The 1st and 2nd year students were enrolled in a pre-engineering course at a local community college, closely tied to the university. The 3rd and 4th year students were enrolled in two programs at different locations: Iron Range Engineering (IRE) and Twin Cities Engineering (TCE). Both programs implement similar PBL pedagogy described above and are in the same Integrated Engineering department in MNSU. Most of the 3rd \& 4th year students focus on the Mechanical and Electrical engineering discipline areas. The community college is closely affiliated with the university and many of its students transfer to the upper division program, so from a practical standpoint considered from one 4-year program for purposes of this study. Demographics of participants are included in Table 1. Due to a small sample size, the gender of participants was not collected, but the programs included in the study have approximately $35 \%$ female students, and the study is assumed to have a similar gender ratio.

Table 1 Courses under survey and student sample demographics

\begin{tabular}{|c|c|c|c|}
\hline Institution type & Course & $\begin{array}{c}\text { Level of } \\
\text { students }\end{array}$ & $\begin{array}{c}\text { \# of students in the } \\
\text { sample }\end{array}$ \\
\hline $\begin{array}{c}\text { Public Comm College } \\
\text { MNSU - IRE - rural } \\
\text { area }\end{array}$ & $\begin{array}{c}\text { Any core technical course in the } \\
\text { program * }\end{array}$ & $3^{\text {rd }}$ and $4^{\text {th }}$ year & 13 \\
\hline $\begin{array}{c}\text { MNSU -TCE - metro } \\
\text { area }\end{array}$ & $\begin{array}{c}\text { Any core technical course in the } \\
\text { program } *\end{array}$ & $3^{\text {rd }}$ and $4^{\text {th }}$ year & 24 \\
\hline
\end{tabular}

${ }^{*}$ Core technical courses are taught in 1-credit competency courses. Each student must take the following: Mechanical Engineering Core - Dynamic Systems, Fluids, Manufacturing Processes, Material Science, Mechanics of Materials, Thermodynamics, Heat Transfer, and Structures 
Electrical Engineering Core - AC Circuits, Digital Logic, Electric Machines, Instrumentation, Signals and Systems, Linear Control Systems, and Three-Phase AC Systems

Business Core - Statistics, Entrepreneurship, Engineering Economics, and Programming/Modeling.

Students also take Advanced technical credits in a focus area to complete the technical course requirements of the Bachelors of

Science degree. They also complete a Design course, and Seminar and Professionalism courses each semester.

This project used a quantitative study with convenience and purposeful sampling methods. We used the Student Response to Instructional Practices (StRIP) instrument, a survey developed to measure students' responses to different types of teaching methods. The end-of-term StRIP instrument [11] includes multiple Likert-scale items (each on a 5-point scale). The two-page survey was completed by pencil and paper by participants at the end of the Spring 2019 semester. See Appendix A. The university's Institutional Review Board approval was sought and granted for this study. The items assess the type of instruction used in the course, students' perceptions of strategies used by the instructor to reduce student resistance, and student response to instruction. The survey is deemed to be valid and reliable [13]. Students in 1st and 2nd years were enrolled in an Introduction to Engineering Design class and were instructed to regard that course as a basis when completing the survey. To maintain consistency with previous studies [13,17] using the StRIP survey so that valid comparisons could be made, our 3rd and 4th year participants were instructed not to base their responses on the workshop style Seminar, Professionalism or Design classes or project work, which are all inherently more active, but to instead use their experience in a core technical course they had taken in the past year.

Results

In order to compare our results in a project-based learning program with a non-PBL program, we directly compared our results with those obtained in a similar study conducted by Kevin Nguyen et al. in 2017 and published in the International Journal of Engineering Education [17]. That study used the same survey instrument and was conducted in three institutions within four engineering courses that "were chosen because they were known to have some level of active learning." They "are not project-based learning programs...but they often use a variety of teaching methods in addition to project-based learning" [18]. Those "active learning engineering instructors use a variety of teaching methods (in addition to lecture)" [18]. Our results are also compared with the Finelli study from 2018 [13]. Studies using the StRIP instrument with engineering students are extremely limited. The comparison of our results from project-based learning students to students in non-PBL but active learning courses adds value and depth to the literature in this area.

Our Research Question 1 is about student perceptions of the instructional strategies used by their instructors. The StRIP survey instrument Question 4 asks respondents how frequently the instructor used the following types of instructional activities: Passive Lecture, Active Lecture, Group Based and Self-directed. Responses were on a 5-point Likert scale: 1-Never, 2-Seldom, 3Sometimes, 4-Often, 5-Always.

Descriptive statistics for the sample size, mean, and standard deviation for the participants' selfreported responses as to instructional activities are shown in Table 2 below. The response summary 
descriptive statistics from both this study $(n=49)$ and the 2017 Nguyen study $(n=179)$ [17] are presented side by side for comparison. A two-tailed test was done to test for statistically significant differences for each type of instruction ( $\operatorname{sig}=.05)$.

Table 2 Types of instruction -- this table compares our study responses to the Nguyen study responses to the "type of instruction" questions.

\begin{tabular}{|c|c|c|c|c|c|}
\hline Types of Instruction: & \multicolumn{2}{|c|}{$\begin{array}{c}\text { This study } \\
\mathbf{n}=\mathbf{4 9}\end{array}$} & \multicolumn{2}{c|}{$\begin{array}{c}\text { Nguyen study } \\
\mathbf{n}=\mathbf{1 7 9}\end{array}$} & Statistically Significant Difference? \\
\hline & Mean & Std Dev & Mean & Std Dev & \\
\hline Passive Lecture & 3.9 & .92 & 3.92 & .71 & No \\
\hline Active Learning Lecture & 2.87 & .99 & 3.24 & .85 & Yes at .02 sig \\
\hline Group Based Activities & 3.63 & 1.02 & 3.4 & .67 & No \\
\hline Self-Directed Activities & 3.06 & 1.09 & 3.31 & .54 & No \\
\hline
\end{tabular}

Results were similar in the two studies, with the only statistically significant difference being in the Active Learning Lecture category. Our PBL students responded that their instructors used Active Learning less frequently than the non-PBL respondents in the Nguyen study reported.

Our Research Question 1 also relates to the instructors' use of explanation and facilitation practices to reduce student resistance, paired with the non-lecture learning strategy. The StRIP survey question 3 provides data for this by asking: "In this course, when the instructor asked you to do in-class, non-lecture activities (e.g. solve problems in a group during class or discuss concepts with classmates), how often did the instructor do the following things?" The factors in this question related to Instructor Strategies are coded "Explanation" and "Facilitation." Questions 3a, 3b, 3c, and 3e relate to instructor "explanation," and Questions 3d, 3f, 3g, and $3 \mathrm{~h}$ relate to instructor "facilitation."

Response choices were as follows: $1=$ Almost never ( $<10 \%$ of the time); $2=$ Seldom $(30 \%$ of the time), $3=$ Sometimes ( $50 \%$ of the time); $4=$ Often $(70 \%$ of the time); and $5=$ Very Often $(>90 \%$ of the time).

Similarly, descriptive statistics for the sample size, mean, and standard deviation for the participants' self-reported responses to the Q3 series for our study are shown in Table 3 below. The response summary descriptive statistics from both this study $(n=49)$, the 2017 Nguyen study $(\mathrm{n}=179)$ [17], and the Finelli study $(\mathrm{n}=1051)$ [13] for this question are also presented, as available. The Finelli study was published in the Journal of College Science Teaching in 2018, used the same StRIP instrument with engineering students and is deemed an appropriate comparative study. A two-tailed test was done to test for statistically significant differences for each type of instruction $(\operatorname{sig}=.05)$ between the current study and both comparative studies. 
Table 3 Instructor Strategies of Explanation and Facilitation to reduce student resistance to non-lecture learning activities. The shaded boxes indicate no detailed data was available.

\begin{tabular}{|c|c|c|c|c|c|c|c|c|c|}
\hline \multirow{2}{*}{\multicolumn{2}{|c|}{$\begin{array}{c}\text { Instructor } \\
\text { Strategies to reduce } \\
\text { student resistance }\end{array}$}} & \multicolumn{2}{|c|}{$\begin{array}{l}\text { This study } \\
\quad \mathrm{n}=49\end{array}$} & \multicolumn{2}{|c|}{$\begin{array}{c}\text { Nguyen } \\
\text { study } \\
\text { n=179 }\end{array}$} & \multirow{2}{*}{$\begin{array}{l}\text { Statistically } \\
\text { Significant } \\
\text { Difference? - } \\
\text { between our } \\
\text { study and } \\
\text { Nguyen study }\end{array}$} & \multicolumn{2}{|c|}{$\begin{array}{c}\text { Finelli } \\
\text { study } \\
\mathbf{n}=\mathbf{1 , 0 5 1}\end{array}$} & \multirow{2}{*}{$\begin{array}{c}\text { Statistically } \\
\text { Significant } \\
\text { Difference? } \\
\text { between our } \\
\text { study and } \\
\text { Finelli study }\end{array}$} \\
\hline & & Mean & $\begin{array}{l}\text { Std } \\
\text { Dev }\end{array}$ & Mean & $\begin{array}{l}\text { Std } \\
\text { Dev }\end{array}$ & & Mean & $\begin{array}{l}\text { Std } \\
\text { Dev }\end{array}$ & \\
\hline \multicolumn{2}{|r|}{ Explanation } & 3.60 & 1.04 & 3.93 & .8 & Yes, at $.02 \mathrm{sig}$ & 4.06 & .82 & Yes, at $.01 \mathrm{sig}$ \\
\hline Q3a & \begin{tabular}{|c|} 
Clearly \\
explained what I \\
was expected to \\
do for the \\
activities
\end{tabular} & 3.77 & .94 & & & & 4.13 & .9 & Yes, at $.01 \mathrm{sig}$ \\
\hline Q3b & $\begin{array}{c}\text { Clearly } \\
\text { explained the } \\
\text { purpose of the } \\
\text { activities }\end{array}$ & 3.57 & .99 & & & & 4.05 & .93 & Yes, at $.01 \mathrm{sig}$ \\
\hline Q3c & $\begin{array}{l}\text { Discussed how } \\
\text { the activities } \\
\text { related to my } \\
\text { learning }\end{array}$ & 3.45 & 1.18 & & & & 4.01 & .95 & Yes, at $.01 \mathrm{sig}$ \\
\hline \multicolumn{2}{|r|}{ Facilitation } & 3.81 & .92 & 4.00 & .68 & No & 3.64 & .85 & Yes, at $.01 \mathrm{sig}$ \\
\hline Q3d & $\begin{array}{c}\text { Solicited my } \\
\text { feedback or that } \\
\text { of other students } \\
\text { about the } \\
\text { activities }\end{array}$ & 2.98 & 1.05 & & & & 3.51 & 1.2 & Yes, at $.01 \mathrm{sig}$ \\
\hline Q3f & $\begin{array}{l}\text { Walked around } \\
\text { the room to } \\
\text { assist me or my } \\
\text { group with the } \\
\text { activity, if } \\
\text { needed }\end{array}$ & 4.38 & .71 & & & & 3.74 & 1.3 & Yes, at $.01 \mathrm{sig}$ \\
\hline Q3g & $\begin{array}{l}\text { Encouraged } \\
\text { students to } \\
\text { engage with the } \\
\text { activities } \\
\text { through his/her } \\
\text { demeanor }\end{array}$ & 3.91 & 1.18 & & & & 3.99 & 1.05 & No \\
\hline
\end{tabular}




\begin{tabular}{|c|c|c|c|c|c|c|}
\hline Q3i & $\begin{array}{l}\text { Confronted } \\
\text { students who } \\
\text { were not } \\
\text { participating in } \\
\text { the activities }\end{array}$ & 3.7 & .88 & 2.92 & 1.28 & Yes, at $.01 \mathrm{sig}$ \\
\hline Q3j & $\begin{array}{c}\text { Invited students } \\
\text { to ask questions } \\
\text { about the } \\
\text { activities }\end{array}$ & 4.06 & .98 & 4.03 & 1.06 & No \\
\hline
\end{tabular}

Results showed statistically significant differences between our PBL student study and comparative studies. Our sample reported less frequent use of Explanation strategies by instructors than both the Nguyen study (sig.02) and the Finelli study (sig.01). The larger Finelli study $(\mathrm{n}=1051)$ showed a mean score for Facilitation that was statistically significantly greater than either of the other studies. The Finelli study results indicated the Explanation strategy was used more than "often", which is higher than either comparison group.

The Facilitation strategy results were mixed. Our results from PBL learners show higher use of some but not all Facilitation strategies. "Walking around the room to assist" and "confronting nonparticipants" in this study were both reported to occur more frequently in our sample than in the comparative samples. The differences reached statistical significance at the .01 level. "Soliciting feedback from students" was reported to be done less frequently in our study (sig.01).

Our Research Question 2 is "What are students' self-reported affective and behavioral responses when their instructors used active learning strategies?" The StRIP survey Question 2 addresses Behavior, Positivity, and Value perceptions by asking participants about their response when the instructor asked them to do in-class, non-lecture activities, such as solve problems in a group or discuss concepts with classmates. Response choices were as follows: $1=$ Almost never $(<10 \%$ of the time); $2=$ Seldom ( $30 \%$ of the time), $3=$ Sometimes ( $50 \%$ of the time); $4=$ Often ( $70 \%$ of the time); and $5=$ Very Often ( $>90 \%$ of the time). Table 4 presents data from this study as well as comparison data from the Finelli study. Detailed comparison data was not available from the Nguyen study. A two-tailed test was done to test for statistically significant differences for each type of instruction ( $\mathrm{sig}=.05)$.

One factor in the Behavioral (Participation) questions reached statistical significance when this study result was compared with the Finelli study. "I planned to give the instructor a lower evaluation because of the activities" was close to "almost never" (mean of 1.27, s.d .57). The Finelli study result was "seldom" (mean of 1.58, s.d. 1.02). The other factors in the Behavioral question series did not reach statistically significant differences. 
Table 4 - This table compares our study responses to the Finelli study responses about the Student Behavioral and Affective Response to Instruction. The students' mean response in this study when the instructor asked students to do in-class, non-lecture activities ranged from 3 (sometimes) to just over 4 (often).

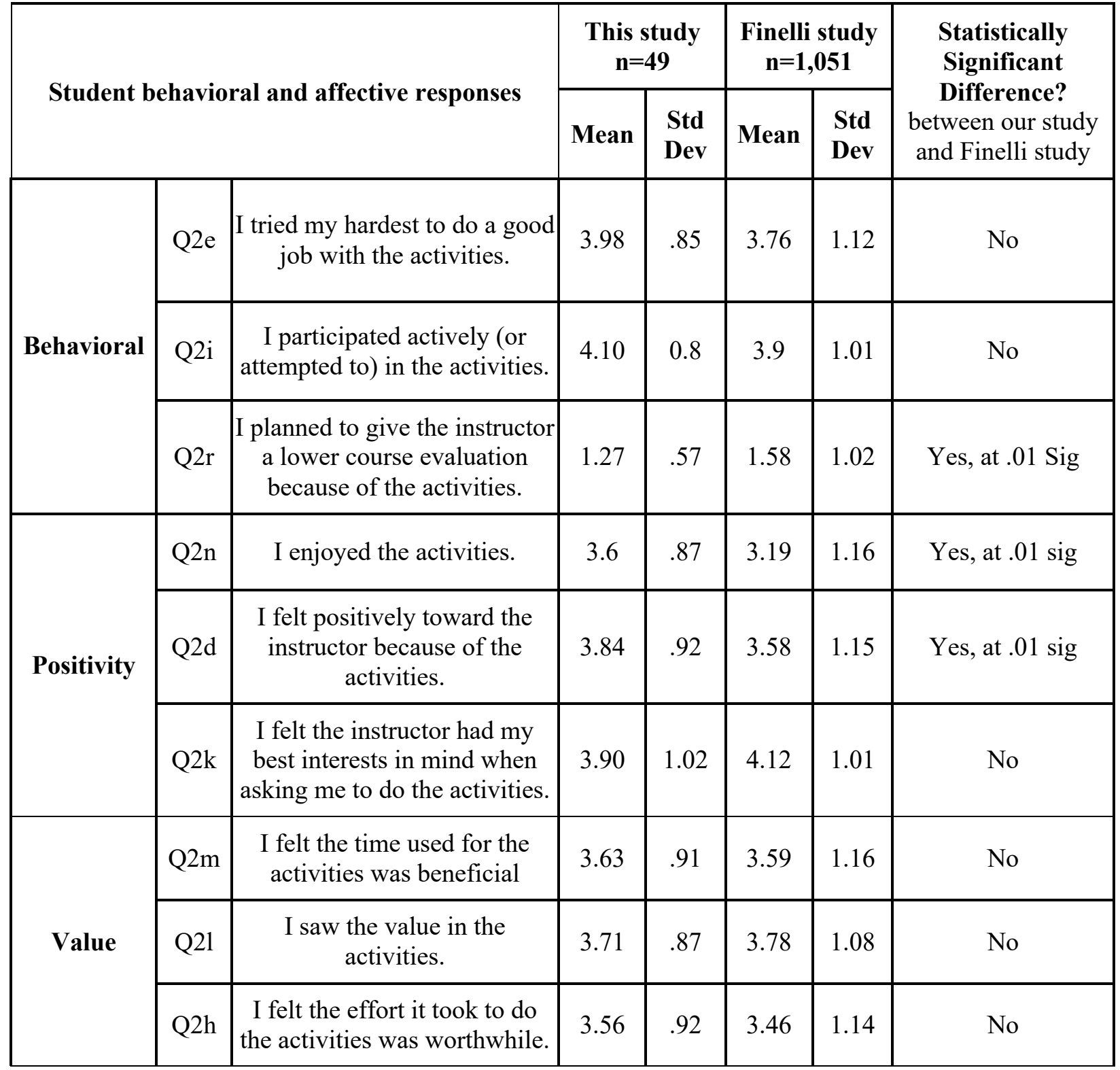

Similarly, our study showed higher responses to the "Positivity" factors than the Finelli study reported, reaching statistical significance at the .01 level. "I enjoyed the activities" had a mean response of 3.60 in our study, compared to 3.19 in the Finelli paper. Similarly, "I felt positively toward the instructor because of the activities" had a mean response of 3.84 in our study, compared to 3.58 in the Finelli paper. This level of detail was not available in the Nguyen paper, so comparison with that study could not be made. 
The StRIP survey Question 5 contains evaluation questions about the course and the teacher being "excellent" and if the student would recommend the instructor to other students. Table 5 presents this study data as well as the Nguyen study data for comparison. Finelli study data was not available for this question. Answer choices for respondents were as follows: $1=$ Strongly disagree; $2=$ Disagree; $3=$ Neutral; $4=$ Agree; and $5=$ Strongly Agree. A two-tailed test was done to test for statistically significant differences for each type of instruction (sig=.05). Our PBL respondents reported higher levels of evaluation for the course and the teacher than the Nguyen study respondents. The standard deviation of the responses was also smaller for each question in our results, meaning that there was more consistency in the responses.

Table 5 This table compares our study responses to the Nguyen study responses to questions on the student evaluations of the course and the teacher. The difference in mean responses was statistically significant at the .01 level for all three questions.

\begin{tabular}{|c|c|c|c|c|c|}
\hline \multirow{2}{*}{$\begin{array}{c}\text { Student evaluation of course and } \\
\text { teacher: }\end{array}$} & \multicolumn{2}{|c|}{$\begin{array}{c}\text { This study } \\
\mathbf{n = 4 9}\end{array}$} & \multicolumn{2}{c|}{$\begin{array}{c}\text { Nguyen study } \\
\mathbf{n = 1 7 9}\end{array}$} & \multicolumn{1}{c|}{$\begin{array}{c}\text { Statistically } \\
\text { Significant } \\
\text { Difference? }\end{array}$} \\
\cline { 2 - 5 } & Mean & Std Dev & Mean & Std Dev & Yes at .01 sig \\
\hline This was an excellent course. & 3.93 & .79 & 3.40 & 1.22 & Yes at .01 sig \\
\hline $\begin{array}{c}\text { The instructor was an excellent } \\
\text { teacher. }\end{array}$ & 4.09 & .75 & 3.66 & 1.19 & Yes at .01 sig \\
\hline $\begin{array}{c}\text { I would recommend this course to } \\
\text { other students. }\end{array}$ & 3.98 & .89 & 3.56 & 1.29 & \\
\hline
\end{tabular}

The StRIP survey Question 6 asks respondents "In how many of your college courses has the instructor asked you to do an in-class activity at least once a week"? This question intends to measure students' prior knowledge of and experience with active learning strategies. Answer choices for respondents were as follows: $1=$ Every one of my college courses; $2=$ Almost all my college courses; 3 = About half of my college courses; 4 = A few of my college courses; and $5=$ none of my college courses. Table 6 presents this study data as well as the Nguyen study data for comparison. Finelli study data was not available. A two-tailed test was done to test for statistically significant differences in mean responses ( $\operatorname{sig}=.05)$. 
Table 6 - Students' prior experience with active learning.

\begin{tabular}{|c|c|c|c|c|c|}
\hline \multirow{2}{*}{$\begin{array}{c}\text { Student prior experience with } \\
\text { active learning }\end{array}$} & \multicolumn{2}{|c|}{$\begin{array}{c}\text { This study } \\
\mathbf{n = 4 9}\end{array}$} & \multicolumn{2}{c|}{$\begin{array}{c}\text { Nguyen study } \\
\mathbf{n = 1 7 9}\end{array}$} & $\begin{array}{c}\text { Statistically } \\
\text { Significant } \\
\text { Difference? }\end{array}$ \\
\cline { 2 - 5 } & Mean & Std Dev & Mean & Std Dev & \\
\hline $\begin{array}{c}\text { In how many of your college courses } \\
\text { as the instructor asked you to do an } \\
\text { in-class activity at least once a week? }\end{array}$ & 2.49 & .97 & 3.09 & 1.13 & Yes at .01 sig \\
\hline
\end{tabular}

The results indicate that students in our study reported more experience with in-class active learning than the comparison group (Nguyen study). The mean of 2.49 in this study is between "almost all" and "about half" of college courses. The Nguyen study mean of 3.09 is "about half" of college courses. The difference is statistically significant at the .01 level.

Discussion

There were some statistically significant differences in results from our study with PBL students and the comparison studies with non-PBL students. Specific discussion for the findings of each StRIP question group follow.

Question set 3 of the StRIP assesses the students' perception on the instructor's ability to explain and facilitate in-class activities. In questions $3 a, 3 b$ and $3 c$ which focus on explanation, we found our program has significantly lower ratings than previous findings on non-PBL learners. There are a few possible reasons behind this result. First, IRE instructors frequently use flipped classroom or hybrid teaching methods. For instance, students are required to watch videos online before class meetings. The 10-min long videos not only include a preview of the class content, but also provide basic guidelines for upcoming in-class activities. In other words, explanations may be already given before class instead of during the class meeting. While the instructor may try to be efficient, unprepared students may be confused and therefore are reluctant to participate. Second, a number of instructors implement similar activities to engage students, such as one-minute papers, jigsaw, gallery walks and game-based quizzes. It is often assumed by the instructor that students are familiar with procedures of those activities.

In terms of facilitation (questions $3 \mathrm{~d}, 3 \mathrm{f}, 3 \mathrm{~g}, 3 \mathrm{i}$ and $3 \mathrm{j}$ ), our results indicate that we are doing a better job in "walking around the class for assistance and confronting students who are not participating" (t-test values of question $3 \mathrm{f}$ and $3 \mathrm{i}$ indicate a statistical significance at 99\% confidence level). Suggested by previous research [21], classroom settings coupled with technology serve a vital role in positive student-teacher interaction. A traditional lecture hall often creates difficulty for instructors to engage students, especially non-participants, our classrooms are designed in the format of roundtables which promote group discussion. To effectively engage nonparticipants, our instructors use strategies such as asking, "Can I offer you some hints to work on this problem?" or letting students work problems together on the white board in order to give them 
a bit of pressure. In addition, it is well known that facilitation realistically becomes less focused with a larger number of students. In IRE and TCE, the average size of a class is around 15 students, which makes it possible for the instructor to engage every individual.

Regarding "solicitation of student feedback about the activities" in question $3 \mathrm{~d}$, there is space for improvement. Similar to typical engineering classes, the instructor tends to assess the activity by quizzing the technical content but often ignores the instant feedback about the activity itself as well as the emotional aspects, i.e. "Do you enjoy this activity?" We solicit information from students about improvement of teaching towards the end of semester, but this would seldom focus on one particular activity and thus not add on much value. We recognize the importance of timely feedback after the activity. If a student notices his/her input is valued and taken into redesign the activity, the feeling of ownership [22] may enhance the engagement.

Student response to active learning is reflected in the question set $2^{[1]}$ summarized in Table 4. Overall, students have acknowledged the benefit and value of in-class activities (questions $2 \mathrm{~m}, 21$ and $2 \mathrm{~h}$ ), which is similar to previous study results. It is worth noting that our students are less likely to turn against the instructor even if they have resistance towards the activities (question $2 \mathrm{~d}$ and 2r). We believe our efforts in building a positive, supportive learning community plays a positive role here. In our PBL environment, team building events, student-led seminars, and outreach programs, encourage a high level of faculty-student collaboration. In addition to the instructor roles, faculty also serve as student project mentors, academic advisors and career counselors. The regular interaction between faculty and students outside the classroom contributes to a positive mutual respect throughout the program. Students may be more forgiving and understanding if the instructor occasionally does not design a very engaging activity for them.

Question 2e and 2i investigate students' behavioral responses to active learning strategies. Our results suggest a slightly better student participation level than previous studies. As Finelli [13] and Nguyen [17] reasoned, part of students' resistance may come from the concern about their grade rather than the activity itself. To combat this potential resistance, we put a heavier grading weight on students' learning process and growth. Consequently, students are aware that the grades are based to some extent on their self-directed learning skills. They may thus seize the opportunity of participating with in-class activities to demonstrate mastery over self-directed learning. This result echoes Tharayil's suggestion to mitigate students' resistance [14] if the instructor grades on participation. Moreover, starting from the lower division (1st and 2nd year), we offer students training to prepare them for the 3rd and 4th year PBL environment, which involves many "trial and errors" occasions. Having a growth-mindset culture [23], we seek to create a safe environment for failure and reward for small success. That being said, even if one does not do well in one activity, the grade would not be negatively impacted, particularly if the student seeks continuous improvement. The scaffolding of incremental steps builds students' confidence for participating in the in-class activities as well. 
Our program's mission includes active and self-directed learning. Why do our students not rate these as occurring more often? It may depend on framing and prior experience. We regularly and often put our students into groups of peers to learn together in Seminar and Professionalism courses and other learning events. Students work in design teams and gain credits toward graduation by completing learning activities in self-directed methods from their design projects. We asked them not to use those primarily active learning events when completing the StRIP survey, but instead to base their answers on their experience in a technical course, which is the most constricted learning environment in our program.

[1] In reference to the original StRIP, we dropped questions $2 a$ ("I disliked the activity") and $2 q$ ("I gave the activity minimal effort"), which are reversed coded.

Conclusion

This study addressed the following research questions:

1. What are students' perceptions about how frequently their instructors used different types of instruction in a project-based engineering program?

2. What are students' self-reported affective and behavioral responses when their instructors used active learning strategies?

3. Do the findings from this study differ significantly from the previous studies on non-PBL program students?

Findings from the StRIP survey in a sample of PBL engineering students $(n=49)$ were compared to two data from larger non-PBL but active learning US engineering programs.

Regarding Research Question \#1, this study found that students in this PBL sample reported less frequent use of most active learning strategies than the non-PBL, active learning respondents from other studies conducted in the US. We interpret this surprising finding in two ways: first, that students in this study were implicitly comparing their in-class activities with their open-ended selfdirected project learning; we agree that in-class activities are more structured and possibly less active. Secondly, the faculty may actually use less active learning than they think they do, or students did not have a clear understanding of what was meant by "active learning" on the survey questions. We plan to have unbiased observers sit in on our class meetings in future and count the use of definitive "active learning" strategies used.

Regarding Research Question \#2, the PBL participants in our study enjoyed their courses and felt positively toward their instructor because of the activities more strongly than in non-PBL studies.

Regarding Research Question \#3, results were mixed. Some of the notable findings that were statistically significantly different from non-PBL studies were that our current PBL students reported less active learning strategies used than in the larger non-PBL programs. This may not be reliable due to small sample size, but it is certainly an item for us to examine more carefully. We 
may have inadvertently biased the results by having the students answer the survey items with one course in mind, which could be the least active part of the program's overall curricula. These findings may not be generalizable to other engineering programs, since our sample was rather small $(n=49)$.

Recommended action steps for other programs

1. For a successful implementation of active learning, the instructor should clearly explain (or have the students create) the learning goals and outcomes for students in the course.

2. Instructors should take steps to build a positive learning community and mentor students in person when class sizes allow. This reduces resistance and fear when students are in an unfamiliar learning environment.

3. Grading plays an essential role in students' resistance. At the beginning, the instructor could shift grading weight more towards the process of learning than the results. Once the burden is removed, students are more likely to participate.

4. Use passive lecture less often; replace it with more active learning techniques, involving students in their construction of knowledge.

5. Explicitly provide more explanation and facilitation strategies during class. Don't assume that students "just know."

6. Arrange for an unbiased researcher/observer to count the uses of active learning strategies, explanation, and facilitation techniques used by the instructor.

7. Ask for immediate feedback from students after an active learning strategy has been used. Collect information on their enjoyment and perceived value of various active learning strategies.

Future work

We plan to continue using the StRIP survey longitudinally and with larger populations and diversity of students in both PBL and non-PBL programs. We also plan to study our instructors' perceptions about how frequently they use different types of instruction and we plan to have an unbiased researcher observe and count them. We recommend looking at the language of the StRIP instrument and evaluating if PBL students with high levels of experience with active learning are framing their answers differently than those with less experience with these pedagogies. 
Appendix A: Presented here are images of the Student Response to Instructor Practices (StRIP) survey ( 2 pages) that was completed in paper-and-pencil format by the participants. Each was tailored with particular instructions for the specific program respondents. Here, "J1" indicates 1st semester Junior, "S2" indicates second semester Senior, etc.

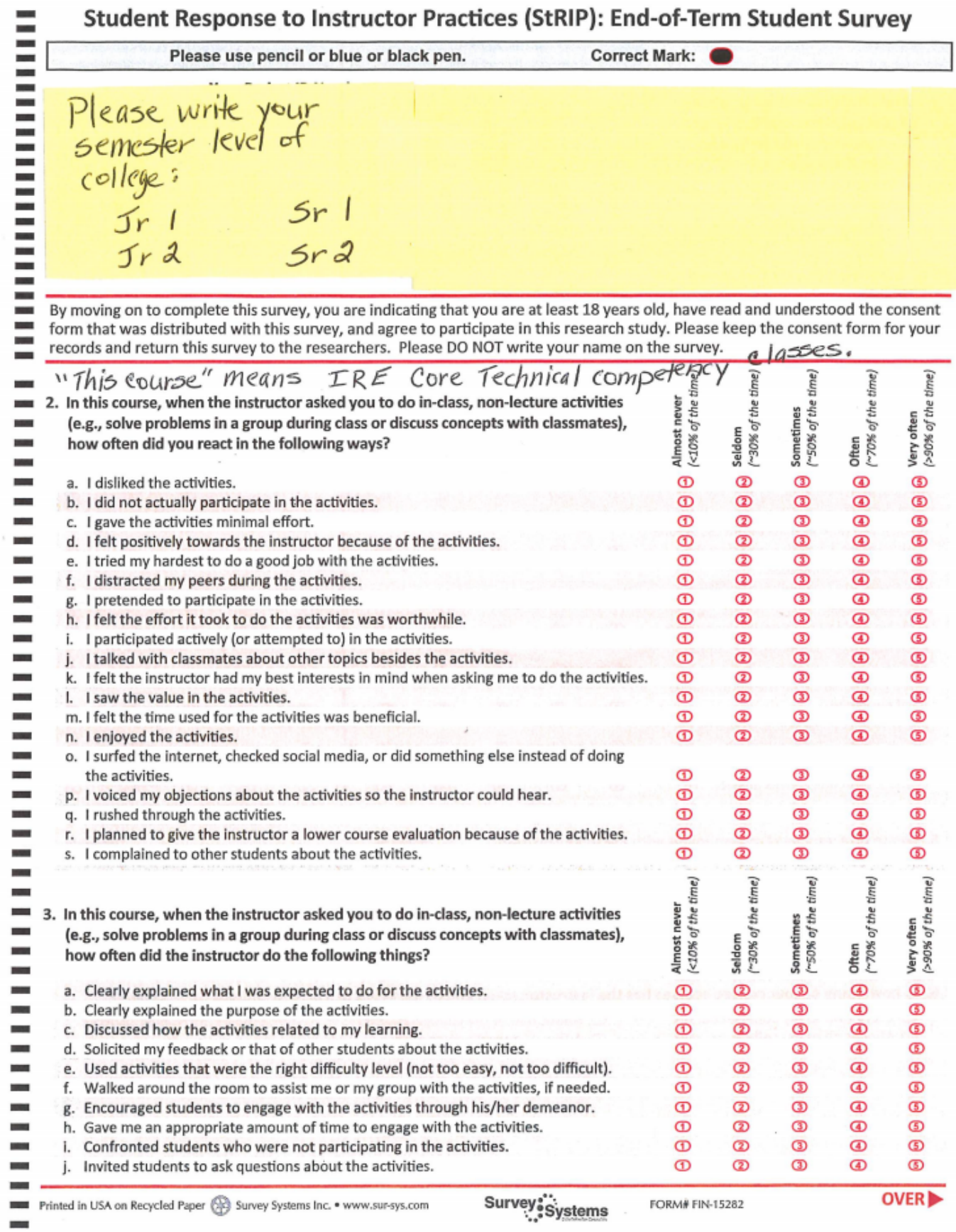


4. For each of the following things, please indicate how often you did each thing in this course and how often you would like to do each in your ideal course.

a. Listen to the instructor lecture during class.

b. Watch the instructor demonstrate how to solve problems during class.

c. Work on problems during class that require me to seek out new information not previously covered in class.

d. Receive an individual grade for group work.

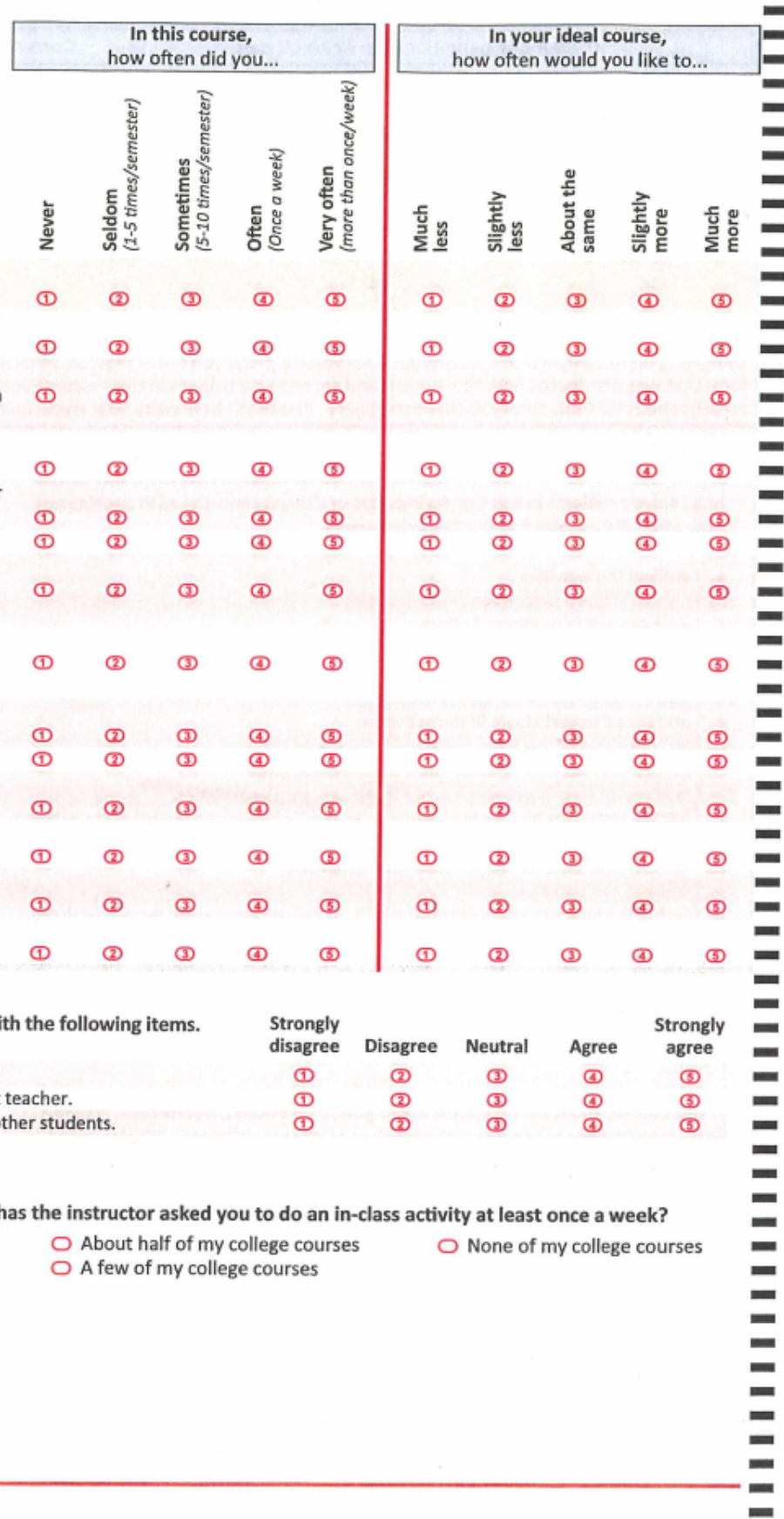

. Be called on personally by the instructor to answer a question during class.

f. Be graded on my class participation.

g. Be asked to answer a question during class on material not previously covered in class.

h. Be given time to think or discuss before answering a question posed by the instructor during class.

i. Discuss concepts with classmates during class.

j. Solve problems in a group during class.

k. Solve problems individually during class.

I. Be graded based on the performance of my group.

m. Preview concepts before class by reading, watching videos, etc.

n. Solve problems during class that have more than one correct answer.

5. Please rate your level of agreement with the following items.

a. Overall, this was an excellent course.

b. Overall, the instructor was an excellent teacher.

c. I would recommend this instructor to other students.

$\bigcirc$ Every one of my college courses

Almost all of my college courses

$\bigcirc$ About half of my college course

None of my college cours 
References

[1] C.C. Bonwell and J.A. Eison, “Active Learning: Creating Excitement in the Classroom," 1991 ASHE-ERIC Higher Education Reports. Washington, DC: ERIC Clearinghouse on Higher Education, The George Washington University, 1991.

[2] David Unwin, Kenneth Foote, and David Dibiase, “Active Pedagogy Leading to Deeper Learning: Fostering Metacognition and Infusing Active Learning into the GIS\&T Classroom," In Teaching Geographic Information Science and Technology in Higher Education, Chichester, UK: John Wiley \& Sons, Ltd., 2012.

[3] B.J. Tewksbury, "Specific Strategies for Using the "Jigsaw" Technique for Working in Groups in Non-Lecture-Based Course," Journal of Geological Education, 43(4), pp. 322326, 1995.

[4] D. Fitzgerald, "Employing think-pair-share in associate degree nursing curriculum," Teaching and Learning in Nursing, 8(3), p. 88-90, 2013.

[5] D.E. Allen, R.S. Donham, and S.A. Bernhardt, Problem-based learning. New Directions for Teaching and Learning, vol 128, pp. 21-29, 2011.

[6] S. Freeman, et al., "Active learning increases student performance in science, engineering, and mathematics. " Proceedings of the National Academy of Sciences of the United States of America, 111(23) pp. 8410-8415, 2014.

[7] S. Martin, D. Rivale, and K.R. Diller, "Comparison of Student Learning in Challenge-based and Traditional Instruction in Biomedical Engineering, " Annals of Biomedical Engineering, . 35(8), pp. 1312-1323, 2007.

[8] T. Russell, et al., "Large Lecture Transformation: Adopting Evidence-Based Practices to Increase Student Engagement and Performance in an Introductory Science Course, ” Journal of Geoscience Education, 64(1): pp. 37-51, 2016.

[9] C. Henderson, A. Beach, and N. Finkelstein, "Facilitating change in undergraduate STEM instructional practices: An analytic review of the literature, "Journal of Research in Science Teaching, 48(8) pp. 952-984, 2011.

[10] C. Henderson, and M.H. Dancy, "Barriers to the use of research-based instructional strategies: The influence of both individual and situational characteristics, "Physical Review Special Topics - Physics Education Research, 3(2), Sept, 2007. Retrieved from https://link.aps.org/doi/10.1103/PhysRevSTPER.3.020102.

[11] M. DeMonbrun, et al., "Creating an Instrument to Measure Student Response to Instructional Practices: Student Response to Instructional Practices, ” Journal of Engineering Education, 106(11), 2017. DOI 10.1002/jee.20162.

[12] J. Eccles, and A. Wigfield, "Motivational Beliefs, Values, and Goals," Annual Review of Psychology, 53(1), pp. 109-132, 2002.

[13] C. Finelli, et al., "Reducing Student Resistance to Active Learning: Strategies for Instructors, ” Journal of College Science Teaching, 47(5), pp. 80-91, 2018.

[14] S. Tharayil, et al., "Strategies to mitigate student resistance to active learning," International Journal of STEM Education, 5(1), p. 7, 2018. 
[15] B.A. Oakley, et al., "Best Practices Involving Teamwork in the Classroom: Results From a Survey of 6435 Engineering Student Respondents, "IEEE Transactions on Education, 50(3), pp. 266-272, 2007.

[16] P. Arce, "The Colloquial Approach: An Active Learning Techniqu,". Journal of Science Education and Technology, 3(3), pp. 145-160, 1994.

[17] K. Nguyen, et al., "Students' Expectations, Types of Instruction, and Instructor Strategies Predicting Student Response to Active Learning, " International Journal of Engineering Education, 33, pp. 2-18, 2017.

[18] K. Nguyen, Personal email communication. Feb 28, 2019.

[19] A. Yadav, et al., "Problem-based Learning: Influence on Students' Learning in an Electrical Engineering Course, "Journal of Engineering Education, 100(2), pp. 253-280, 2011.

[20] M.J. Prince, and R.M. Felder, "Inductive Teaching and Learning Methods: Definitions, Comparisons, and Research Bases, ” Journal of Engineering Education, 95(2), pp. 123-138, 2006.

[21] D. Lee, A.S. Morrone, and G. Siering, "From swimming pool to collaborative learning studio: Pedagogy, space, and technology in a large active learning classroom, "Educational Technology Research and Development, 66(1), pp. 95-127, 2018.

[22] L. Mikalayeva, "Motivation, Ownership, and the Role of the Instructor in Active Learning

1," International Studies Perspectives, 17(2), pp. 214-229, 2015.

[23] D.S. Yeager, et al., "A national experiment reveals where a growth mindset improves achievement," Nature, 573(7774), pp. 364-369, 2019. 